\title{
THE ROLE OF MACROSCOPIC TURBULENT DIAMAGNETISM IN ENSURING LONG-TERM STABILITY OF SUNSPOTS
}

\author{
V.N. Krivodubskij \\ Astronomical Observatory, Taras Shevchenko National University of Kyiv, Kyiv, Ukraine \\ krivod2@ukr.net
}

\begin{abstract}
We investigated the role of macroscopic turbulent diamagnetism in ensuring the long-term stability of the equilibrium state of the sunspots. The physical meaning of macroscopic diamagnetism of turbulent plasma is expulsion of a large-scale magnetic field from areas with increased turbulence intensity to areas with reduced turbulence. We follow the idea of Krause \& Rüdiger (1975) that a strong magnetic field of a sunspot modifies the structure of turbulence in spot umbra, so it becomes two-dimensional. In addition, we take into account the strong magnetic suppression of turbulence in the spot, where it becomes less intense than the turbulent convection around the spot. As a result, a relatively thin transitional vertical layer of permeable convection (convective overshot layer) should be formed between these sections, in which the intensity of turbulent pulsations decreases noticeably in the transverse direction during the transition from the convection section to the spot. In this permeable convection layer, the effect of turbulent diamagnetic displacement of the magnetic field from the convection region to the sunspot occurs. Owing to the two-dimensional turbulent diffusion, the magnetic field of the spot spreads outwards, while the intense turbulent pulsations in the convection region return the magnetic field in the opposite direction, back to the spot. Therefore, these two oppositely directed processes of magnetic field transfer in the horizontal plane compete with each other. As a result, the magnetic fields that are transferred due to turbulent diffusion outward from the sunspot will be thrown backward into the spot due to strong external turbulent convection. In our opinion, this effect should ensure long-term stability of the equilibrium state of the magnetic field of sunspots and support them in the form of isolated vertical unipolar magnetic force tubes.
\end{abstract}

Keywords: sunspots, magnetic fields, turbulence, convective overshoot layer, macroscopic turbulent diamagnetism.

АНОТАЦІЯ. Ми дослідили роль макроскопічного турбулентного діамагнетизму у забезпеченні довготривалої стабільності рівноважного стану сонячних плям. Фізичний сенс макроскопічного діамагнетизму турбулентної плазми полягає у витисненні крупномасштабного магнітного поля із ділянок 3 підвищеною інтенсивністю турбулентності в ділянки зі зниженою турбулентністю. Ми дотримуємось ідеї Краузе та Рюдігера (Krause \& Rüdiger, 1975) про те, що сильне магнітне поле сонячної плями змінює структуру турбулентності в тіні плями, тому тут вона стає двовимірною. Крім того, ми беремо до уваги сильне магнітне пригнічення турбулентності в плямі, де вона стає менш інтенсивною, ніж турбулентна конвекція навколо плями. В результаті між цими ділянками повинен утворитися відносно тонкий перехідний вертикальний шар проникної конвекції (конвективний овершут шар), в якому інтенсивність турбулентних пульсацій значно зменшується в поперечному напрямку при переході від ділянки конвекції до плями. У цьому шарі проникної конвекції виникає ефект турбулентного діамагнітного витіснення магнітного поля із ділянки конвекції до сонячної плями. Завдяки двовимірній турбулентній дифузії магнітне поле плями поширюється назовні, тоді як інтенсивні турбулентні пульсації у ділянці конвекції повертають магнітне поле в зворотному напрямку, назад до плями. Тому ці два протилежно спрямовані процеси перенесення магнітного поля в горизонтальній площині конкурують між собою. В результаті, магнітні поля, які внаслідок турбулентної дифузії переносяться назовні із сонячної плями, будуть відкинуті назад в пляму через сильну зовнішню турбулентну конвекцію. На наш погляд, цей ефект повинен забезпечити довготривалу стійкість рівноважного стану магнітного поля сонячних плям і підтримувати їх у вигляді ізольованих вертикальних однополярних магнітних силових трубок.

Ключові слова: сонячні плями, магнітні поля, турбулентність, шар проникної конвекції, макроскопічний турбулентний діамагнетизм.

\section{Introduction}

Observations show a strange property of surface magnetic fields on the Sun, which tend to spontaneously concentrate into widely spaced isolated magnetic flux tubes (MFT) of the same polarity in the form of sunspots. The question arises of how to explain the long-term stability of the equilibrium state of the spot after the fields float to the surface, when the MFTs in the subphotosphere layers are close to the vertical position, despite the mutual repulsion of fields of the same polarity. In connection with this problem, we investigated the role of macroscopic turbulent diamagnetism in ensuring the equilibrium state of vertical MST. 


\section{Macroscopic turbulent diamagnetism of plasma}

Turbulent viscosity of plasma in absence of magnetic field is described by the following relationship

$$
v_{\mathrm{T}} \approx(1 / 3) u l \text {, }
$$

where $u$ and $l$ are the rms effective velocity and the characteristic scale of turbulent vortices. Zeldovich (1956) discovered, and Weiss (1966) then confirmed, that vortices in turbulent plasma are capable of expulsion magnetic flux out of the turbulent region. Later, Rädler (1968) called the revealed phenomenon as "the macroscopic diamagnetic effect". The physical sense of macroscopic diamagnetism of turbulent plasma (Krause \& Rädler, 1980; Vainshtein, Zel'dovich \& Ruzmaikin, 1980; Zeldovich, Ruzmaikin \& Sokoloff, 1983) is expulsion of the mean (large-scale) magnetic field from areas of high-conductivity plasma with increased intensity of turbulent motions to places with less developed turbulence along the gradient of turbulent viscosity $v_{\mathrm{T}}$ with the effective rate

$$
\mathbf{U}_{\mu}=-\nabla v_{\mathrm{T}} / 2
$$

The expulsion of initially homogeneous magnetic field from the region of highly conductive plasma with turbulent vortex motions can be explained as follows. At first, the magnetic field frozen into the highly conductive plasma is strongly entangled by vortices and its scale decreases rather quickly. When the scale becomes small enough, the ohmic dissipation (which is determined by magnetic viscosity $v_{\mathrm{m}}=\mathrm{c}^{2} / 4 \pi \sigma, \sigma$ is the gas-kinetic conductivity of plasma, and $c$ is the speed of light) enters into action, and the field almost disappears in this region. Ultimately, this phenomenon can be interpreted as the expulsion of the field from the region with turbulent motions.

Within the framework of macroscopic magnetohydrodynamics, the decay process of the mean magnetic field $\mathbf{B}$ in turbulent plasma is described by the diffusion equation

$$
\partial \mathbf{B} / \partial t=\operatorname{rot}\left(\mathbf{U}_{\mu} \times \mathbf{B}\right)+\left(v_{\mathrm{m}}+v_{\mathrm{T}}\right) \Delta \mathbf{B} .
$$

The first term in the right side of this equation describes magnetic field transfer due to macroscopic turbulent diamagnetism, while the second term describes magnetic field attenuation due to ohmic dissipation and turbulent diffusion.

It is important to remember that there are frequent situations in space and in the solar plasma in particular when characteristic sizes of vortices are large enough to form zones between turbulent convective structures and regions without perturbations, where gradual decrease in turbulent vortices intensity occurs. This structure, referred to as "the convective overshoot layer", is formed at the boundary between the solar convection zone (SCZ) and the radiative interior of the Sun (Roxburgh, 1978; Spiegel \& Weiss, 1980; Van Ballegooijen, 1982).

A noticeable positive radial gradient of the turbulent velocity near the bottom of the SCZ in the overshoot convection layer causes an intense downward diamagnetic displacement of the field, which acts against magnetic buoyancy and thus contributes to the long-term retention of the field (Krivodubskij, 1984, 2005; Kryvodubskyj, Rüdiger \& Kitchatinov, 1994).

We believe that favorable conditions for the appearance of a convective overshoot layer can also be created near the surface of the Sun at the transverse transition from the vertical MFT of the sunspot to the environment convection region. Let's explore in more detail how these conditions are created.

\section{Turbulence degeneration at strong magnetic field in sunspot}

It is well known that strong magnetic fields appreciably suppress the turbulent eddies intensity. However, laboratory experiments by Kit \& Tsinober (1971) showed that a strong magnetic field does not completely suppress turbulence. Rather, it leads to a change in the spatial structure of turbulence. By a strong magnetic field turbulence is caused to become two-dimensional: a variation of the turbulent velocity in the direction parallel to the magnetic field is strongly inhibited.

It should be expected that the strong magnetic field in a sunspot will cardinally modify the structure of turbulent motions in the sunspot umbra in comparison with the turbulent convection in sunspot vicinity in the more profound layers of the SCZ. Indeed, according to Krause \& Rüdiger (1975), the turbulent motions in deep sunspot layers by the influence of the strong homogeneous vertical magnetic field $(B \approx 3000 \mathrm{G})$ degenerates into a two-dimensional structure, which does not changes along the magnetic field (Fig. 1). It was believed that the processes causing the decay of the magnetic field take place in the deeper layers, where the field can be assumed vertical. Thus, this model does not take into account the magnetic lines of force spread in the upper layers near the surface of the Sun. In this case, the rate of magnetic field decay in a

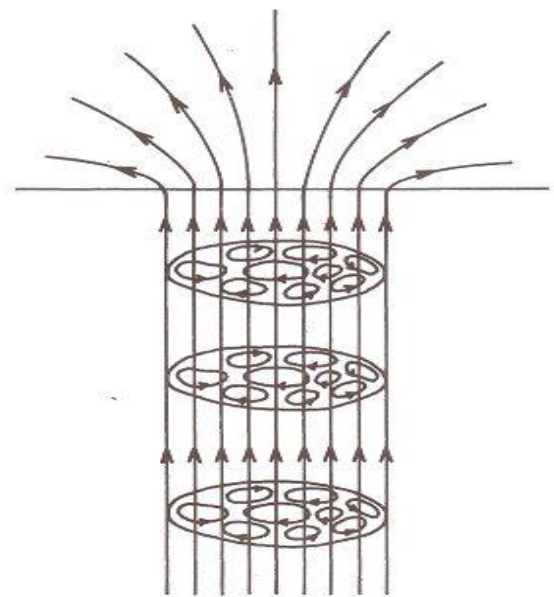

Figure 1: Sunspot magnetic field model. The magnetic field is assumed to be directed perpendicular to the Sun's surface. The turbulent motions in deep sunspot layers by influence of the strong homogeneous vertical magnetic field degenerate into a two-dimensional structure. Figure was taken from the paper (Krause \& Rüdiger, 1975). 
transverse direction is determined by the two-dimensional turbulent viscosity (Krause \& Rüdiger 1975),

$$
v_{\mathrm{T}}^{(2)} \approx(1 / 2) u l
$$

In addition, a strong magnetic field causes noticeably suppression of turbulent convection (which leads to decrease in the parameters $u$ and $l$ ) in the sunspot umbra (Obridko \& Teplitskaya, 1978; Krat, Karpinsky \& Pravdjuk, 1972). Therefore it should be expected that the turbulent viscosity in the sunspot will be smaller then this one the convective region outside of the spot.

\section{Vertical turbulent overshoot layer in the vicinity of the sunspot}

We will proceed from the above mentioned model of the magnetic field of the sunspot. According to Solov'ev (1976) the magnetic field decreases sharply from 2000$4000 \mathrm{G}$ in the sunspot to $500-700 \mathrm{G}$ in the convective region. We believe that in the convective region with a weak magnetic field, intense turbulent convection has a three-dimensional structure, while in the sunspot with a strong magnetic field, turbulent convection degenerates into a weak two-dimensional structure. As a result, on the spot outer boundary a relatively thin vertical transitional layer of permeable convection (convective overshot layer) should be formed in which the intensity of turbulent pulsations decreases noticeably in the transverse direction during the transition from the convective region to the sunspot (Fig. 2). Therefore, favorable conditions appear in this boundary layer for transverse (horizontal) macroscopic diamagnetism that can affect the reconstructing of the sunspot magnetic field. Intense turbulent pulsations in the convection region return the magnetic field backward to the sunspot, which permeates due to turbulent diffusion in the opposite direction, outward from the sunspot.

Therefore, two oppositely directed processes of magnetic field transfer in the horizontal plane compete with each other. Namely, the magnetic fields that are transferred due to turbulent diffusion outward from the sunspot to the convection region (the second term in the right side of eq. (3)) will be thrown backward into the sunspot due to the gradient of turbulent viscosity in overshoot layer (the first term in the right side of this equation). In our opinion, this effect must keep magnetic fields of sunspots and support them in the form of long-term isolated vertical MFTs.

\section{Transverse (horizontal) turbulent diamagnetic transfer of fields from the convection region to the sunspot}

To verify our assumption how turbulent diamagnetism helps the sunspot magnetic fields to keep their structure in for a long time, we calculated the coefficient of turbulent viscosity outside a sunspot in the convection region and compare it with the calculated turbulent viscosity in the sunspot.

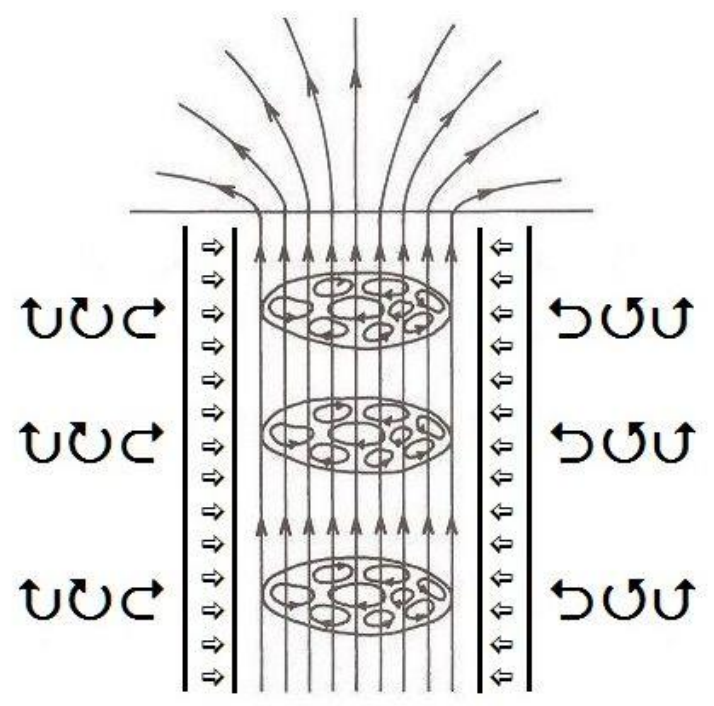

Figure 2: Vertical turbulent overshoot layer at the boundary between an MFT and surrounding convection region. In this layer (with thickness $d$ ) the intensity of turbulent pulsations decreases noticeably in the transverse direction at the transition from the convective region to the sunspot. Due to weak two-dimensional turbulent viscosity in sunspot the magnetic field permeates outwards, however intense threedimensional turbulent vortices in the convection region (large eddies) return this magnetic field backward to the sunspot. The direction of the macroscopic diamagnetic field transfer to the spot (with the rate $\mathbf{U}_{\mu}=-\nabla v_{\mathrm{T}} / 2$ ) is shown in the overshoot layer by light arrows.

For the convective region we use the following values of turbulent parameters at a depth of $\mathrm{z} \approx 400 \mathrm{~km}$ in the SCZ model by Stix $(2003): u \approx 2 \times 10^{5} \mathrm{~cm} / \mathrm{s}, l \approx 4 \times 10^{7} \mathrm{~cm}$. Then the turbulent viscosity in the convection region is estimated to be $v_{\mathrm{T}} \approx(1 / 3) u l \approx 3 \times 10^{12} \mathrm{~cm}^{2} / \mathrm{s}$.

As noted above, the strong magnetic field of sunspot stimulates the degeneration of three-dimensional turbulence into two-dimensional one (Krause \& Rüdiger, 1975). The following turbulent parameters for sunspot umbra were taken for calculating: $u \approx 1.3 \times 10^{5} \mathrm{~cm} / \mathrm{s}$ (Obridko \& Teplitskaya, 1978 ); $l \approx 1.5 \times 10^{7} \mathrm{~cm}$ (Krat, Karpinsky \& Pravdjuk, 1972). As a result of calculations, the following estimate was obtained: $\nu_{\mathrm{T}}^{(2)} \approx(1 / 2) u l \approx 2 \times 10^{12} \mathrm{~cm}^{2} / \mathrm{s}$.

It is essential that turbulent viscosity in the convective region exceeds this one in the sunspot. Therefore, our estimates confirm that the effect of turbulent diamagnetic expulsion (in the horizontal plane) of magnetic field from the convection region toward the sunspot must inevitably appear in the boundary overshoot layer (which occurs between a vertical MFT and surrounding medium).

Following (Solov'ev, 1976), we assume that the thickness $d$ of the transitional layer of penetrating convection between the vertical MCT of the spot and the surrounding three-dimensional turbulence is $100 \mathrm{~km}$.

We can estimate the velocity of diamagnetic transfer ("dragging") of magnetic field from the convection region 
to the sunspot using the obtained parameters of turbulent viscosity

$$
U_{\mu} \approx-\left(\nu_{\mathrm{T}}-\nu_{\mathrm{T}}^{(2)}\right) / 2 d \approx-\left(\nu_{\mathrm{T}}-\nu_{\mathrm{T}}^{(2)}\right) / 2 d \approx-10^{5} \mathrm{~cm} / \mathrm{s} .
$$

The minus sign indicates that the magnetic field is expelled from the convection region to the sunspot. The time of diamagnetic "dragging" of the field toward the sunspot is next: $t_{\mu} \approx d /\left|U_{\mu}\right| \approx 100 \mathrm{~s}$.

Therefore, the regime of stable keeping the magnetic field in the sunspot is settled fairly fast (over the time that is less than the lifetime of granulation cells on solar surface) due to macroscopic turbulent diamagnetic effect in the convection region. The disintegration of the sunspot at its inner side is determined by slow magnetic diffusion due to relatively low turbulent viscosity of the sunspot umbra. The sunspot decay at its outer side is due to diffusion under conditions of enhanced turbulent convection intensity, which yields an accelerated rate of magnetic attenuation that can be interpreted as an "expulsion" of the magnetic field from surrounding medium backward to the sunspot umbra. It is this second accelerated rate of magnetic field attenuation at the outer side of the sunspot that plays an essential role in long-term stability of equilibrium state of vertical MFTs in sunspots (effect of macroscopic diamagnetic field expulsion from the convection region to the sunspot).

\section{Conclusion}

We considered the difference in turbulent vortices intensities between the sunspot umbra (where turbulent vortices are suppressed by a strong magnetic field) and the surrounding plasma without magnetic fields (the convection region, where suppression of turbulent vortices due to magnetic field is absent). As a result, a relatively thin transitional vertical convective overshoot layer must be formed between these sections, in which the intensity of turbulent pulsations decreases significantly in the transverse direction during the transition from the convection region to the spot.

This approach enabled us to reveal the effect of macroscopic diamagnetic expulsion of magnetic field from the convection region to the sunspot (transverse turbulent diamagnetism), which can play an essential role in long-term stability of equilibrium state for vertical MFTs.
Acknowledgements. This study was funded by grant number 19BF23-03 of Taras Shevchenko National University of Kyiv.

\section{References}

Kit L.G., Tsinober A.B.: 1971, Magnitnaja gidrodinamika, 1971/3, 27.

Krat V.A., Karpinsky V.N., Pravdjuk L.M.: 1972, Sol. Phys., 26, 305.

Krause F., Rädler K.-H.: 1980, Mean Field Magnetohydrodynamics and Dynamo Theory, Berlin: Akademie-Verlag.

Krause F., Rüdiger G.: 1975, Sol. Phys., 42, 107.

Krivodubskij V.N.: 1984, Soviet Astronomy, 28, No.2, 205.

Krivodubskij V.N.: 2005, Astron. Nachr., 326, No.1, 61.

Kryvodubskyj V.N., Rüdiger G., Kitchatinov L.L.: 1994, Visnyk Kyiv. Universytetu. Astronomija, 33, 55.

Obridko V.N., Teplitskaya R.B.: 1978, Itogi Nauki Tekh., Ser.: Astron., 14, 7.

Rädler K.-H.: 1968, Z. Naturforsch., A: Astrophys., Phys., Phys. Chem., 23, 1841.

Roxburgh I.W.: 1978, Astron. Astrophys., 65, 281.

Solov'ev A. A.: 1976, Astron. Zh., 53, 140.

Spiegel E.A., Weiss N.O.: 1980, Nature, 287, 616

Stix M.: 2003, The Sun. Berlin: Springer.

Vainshtein S. I., Zel'dovich Ya. B., Ruzmaikin A. A.: 1980, Turbulent Dynamo in Astrophysics, Moscow: Nauka, 352 p. [in Russian].

Van Ballegooijen A.A.: 1982, Astron. Astrophys., 113, 99.

Weiss N.O.: 1966, in Proc. Roy. Soc. London, A293, 310

Zel'dovich Ya. B.: 1956, Zh. Eksp. Teor. Fiz., 31, 154.

Zeldovich Ya.B., Ruzmaikin A.A., Sokoloff D.D.: 1983, Magnetic Fields in Astrophysics, New York: Gordon and Breach, $381 \mathrm{p}$. 